Şırnak Üniversitesi

Ilahiyat Fakültesi Dergisi

Sayı 27 Aralık 2021

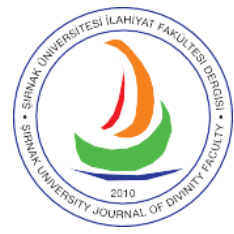

e-ISSN 2667-6575
Şırnak University

Journal of Divinity Faculty

Issue 27 December 2021

\title{
Hükümlerde Değişimle İlgili Yapılan Bazı Yorum ve Değerlendirmelere Usûlı̂ Bir Yaklaşım
}

A Procedural Approach to Some Comments and Evaluations Regarding the Change in Provisions

\section{İsmet KALKAN}

Dr. Öğr. Üyesi, Adıyaman Üniversitesi, İlahiyat Fakültesi, İslam Hukuku Ana Bilim Dalı Assistant Professor, Adiyaman University, Faculty of Divinity, Department of Islamic Law

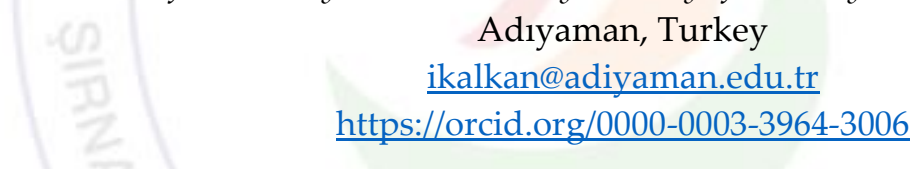

Makale Bilgisi / Article Information

Makale Türü / Article Types: Araştırma Makalesi / Research Article

Geliş Tarihi / Received: 14 Eylül / September 2021

Kabul Tarihi / Accepted: 8 Kasim / November 2021

Yayın Tarihi / Published: 15 Aralık / December 2021

Sayı / Issue: 27 Sayfa / Pages: 85-109

Atıf / Cite as: Kalkan, İsmet. "Hükümlerde Değişimle İlgili Yapılan Bazı Yorum ve Değerlendirmelere Usûlî Bir Yaklaşım [A Procedural Approach to Some Comments and Evaluations Regarding the Change in Provisions]". Şırnak Üniversitesi İlahiyat Fakültesi Dergisi - Şırnak University Journal of Divinity Faculty 27 (December 2021), 85-109. https://doi.org/10.35415/sirnakifd.995210

Etik Beyanı / Ethics Declaration: Bu makalede bilimsel araştırma ve yayın etiği ilkelerine riayet edilmiştir. Makale etik izin gerektirmeyen bir çalışma olup en az iki hakem tarafından incelenmiş ve intihal içermediği teyit edilmiştir./ In this article, the principles of scientific research and publication ethics are respected. The article is a study that does not require ethical permission. It has been reviewed by at least two referees and was confirmed that it did not contain plagiarism.

Copyright $\odot$ Published by Şırnak Üniversitesi, İlahiyat Fakültesi / Şırnak, Türkiye (Şırnak University, Faculty of Divinity, Şırnak, 73000 Turkey). 


\section{Özet}

İnsana ve insanî olana nispetle değişmenin kaçınılmaz olduğu gibi, ezmanın tağayyürü ile de ahkâmın tağayyürü inkâr olunamaz. Çünkü insanlar, varlıklarını istikrarlı bir şekilde devam ettirebilmek için ihtiyaç duydukları bilgi ve imkâna her zaman aynı düzeyde ve aynı kalitede ulaşamamaktadır. Kişiye ve topluma göre değişen farklı düzeydeki ihtiyaç ve gereksinimler ile insan yaşamını derinden etkileyen savaş, doğal felâket ve benzeri olumsuzluklar da insan ve toplum davranışlarının hızlı bir şekilde değişmesine sebep olmaktadır. Bu davranış değişikliği, toplumsal örf ve adetlerde farklılaşmayı da tabiatiyla beraberinde getirmektedir. Topyekûn kâinattaki bu hızlı değişim ve dönüşüm, hayat standartlarında olduğu gibi insan haklarını düzenleyen beşerî yasalarda da kısmî ya da külli değişiklikler şeklinde kendisini gösterebilmektedir. Örfî davranışlardaki değişime paralel olarak dinî hüküm ve fetvalarda da değişim söz konusudur. Ancak beşerî kanun ve yasaları etkisi altına alan bütün değişim enstrümanlarının, İlâhî yasalar için aynı düzeyde etkili olduğunu söylemek mümkün değildir. İslam hukukunda fakihlerin genelinin itibarına göre; kat'î şer'î hükümler ictihâd konusu olmadıkları için değişime kapalıdır. Değişime açık olan hükümler ise zannî delille sabit olan hükümler ile hakkında nas ve icmâ' bulunmayan hükümlerden ibarettir. Haddi zatında az sayıdaki değişime kapalı bu hükümler, aynı zamanda değişime açık hükümler için de bir istikrar unsurudur. Zira İslam hukukunun; adaletin temini, zararın def'i, harac ve fesadın giderilmesi ve kolaylık prensipleri gibi fert ve toplum maslahatını tesise dayalı evrensel bir hukuk sistemi olması da değişime açık olan hükümlerde ictihâd tariki ile değişimi zorunlu kılmaktadır. Fıkıh literatürümüz, hükümlerde değişimin mümkün olduğunu gösteren pek çok örnekle doludur. Fetvada değişim konusu, eski yeni ilmi çalışmaların birçoğunda, "hükümde değişim" başlığı altında ele alınmaktadır. Ülkemizde de bu konu ile ilgili yazılmış pek çok ilmî makale ve kitap bulunmaktadır. Konu ile ilgili yapılan çalışmalar incelendiğinde, bunlardan bazılarının, konuyu; ilmî perspektiften uzak, hikmet-i teşri' ve usul ilminden bağımsız olarak ele almış oldukları dikkatlerden kaçmamaktadır. Bu çalışmalarda hükümlerde değişme tezinin, fetvada değişme ile istidlal edilmiş olması, bunun en bariz örneğidir. Ayrıca bu çalışmaların bir kısmında konunun, yine usul ilminden bağımsız olarak ele alınmış olmasından kaynaklanan müteselsil yorum hatalarına da rastlamak mümkündür. Eski kaynakların bir kısmı ile bu konu ile ilgili yapılan Türkçe çalışmalarda konunun, "hükümlerde değişme" başlığı altında ele alınmış olması, müteselsilen tekrar eden bu yorum hatalarına örnek olarak gösterilebilir. Ayrıca bu çalışmaların bazılarında, taabbudî hükümlerin sınırlarını geniş tuttukları gerekçesiyle mütekaddim fukaha, mütekaddim fukahanın ictihâdlarını kutsadıkları gerekçesi ile de müteahhir fukaha kıyasıya eleştirilmektedir. Bu çalışmada, usul ilmi ve fukahanın çoğunluğunun görüşü esas alınarak hükümde değişmenin; mahiyeti, sınırları ve yöntemi konusu kısaca ele alınacaktır. Özellikle konu ile ilgili yapılan çalışmaların bazılarında, dikkatleri çeken usulî hatalar, birkaç örnek üzerinden analiz edilecektir. Ayrıca bu çalışmalarda, konu ile ilgili farklı görüşleri sebebiyle kategorize edilen âlim ve araştırmacıların iddia edilen gruplara nispeti ile bu grupların stratejileri hakkında yapılan tenkit ve eleştiriler değerlendirilip, bu konu ile ilgili bir durum tespiti yapılacaktır.

Anahtar Kelimeler: İslam Hukuku, Değişim, Hüküm, İctihâd, Makâsıd, Örf, Usûl, Vesâil. 


\begin{abstract}
Just as humans change, the judgments will inevitably change with the advance of time. That is because people do not always have access to the information and opportunity which they need to maintain their existence stably at the same level and with the same quality. Different levels of needs and requirements that vary according to the person and society, and some negativities such as wars, natural disasters that deeply affect human life also causes rapid changes in human and social behaviour. This change in behaviour naturally brings about differentiation in social customs and traditions. This rapid change and transformation in the entire universe can manifest itself in the form of partial or total changes in human laws regulating human rights as well as in living standards. Parallel to the change in customary behaviour, there are also changes in religious decrees and fatwas. However, it is not possible to say that all this rush of change that affects human acts and laws are equally effective for divine laws. According to the general consideration of the jurists in Islamic law; Since the absolute Shariah rulings are not the subject of ijtihad, they are closed to change. The provisions that are open to change consist of the provisions that are fixed by conjectural evidence and the provisions about which there is no codex and consensus. As a matter of fact, the few provisions that are not subject to change are also an element of stability for the provisions that are open to change. Because, the fact that Islamic law is a universal legal system based on establishing the welfare of the individual and society by the principles such as ensuring justice, redressing the damage, eliminating extortion and corruption, and facilitating, necessitates the change in the provisions that are open to change via ijtihad. Our fiqh literature is replete with many examples that show that change in provisions is possible. The subject of change in the fatwa is discussed under the title of "change in the decree" in many of the old and new scholarly studies. There are many scholarly articles and books written on this subject in our country. When the studies on the subject are examined, it does not go unnoticed that some of them have dealt with it independently of the reason of the legislation or methodology and far from a scientific perspective. The most obvious example of this is that in these studies, the thesis of change in decrees was substantiated with change in fatwa. In addition, in some of these studies, it is possible to encounter several interpretation errors arising from the fact that the subject has been handled independently of discipline of methodology. The fact that some of the old sources and Turkish studies on this subject dealt with the subject under the title of "change in the provisions" can be given as an example of these repeated interpretation errors. In addition, in some of these studies, the former jurists are fiercely criticized for keeping the boundaries of divine decrees wide, and the later jurists for sanctifying the ijtihâds of the former jurists. In this study, the nature, limits and method of change in the provision will be briefly discussed based on the discipline of methodology and the opinion of the majority of the jurists. Especially methodological errors that attract attention in some of the studies on the subject will be analysed through a few examples. In addition, the relation of scholars and researchers categorized in these studies to the alleged groups due to their different views on the subject and the criticisms and commentaries made about the strategies of these groups will be evaluated, and due diligence will be made on this issue.
\end{abstract}

Keywords: Islamic Law, Change, Judgment, İjtihad, Maqāsid, Metodology, Custom, Wasāil. 


\section{Giriş}

Hüküm ve fetvada değişim olgusu öteden beri tartışılagelen konulardan birisi olmuştur. Fetvada değişme imkânı, İslam ümmetinin maslahatını temin ve hile-i şer'iyyeye tevessül ihtimalini de ortadan kaldırması bakımından oldukça önemli ve hatta gereklidir. Ancak bundan daha da önemlisi, yapılacak olan değişimin yöntemini iyi tespit etmektir. Zira değişimin, âlimlerin çoğunluğunun furû' üretme mekanizması olarak itibar ettikleri usûl ilminin dışına çıkılarak gerçekleştirilmeye çalışılması halinde, bu hayırlı faaliyetin hukukun bütünlüğü ilkesine zarar verebilecek şerli bir faaliyete evrilme ihtimali her zaman mevcuttur. Bu ihtimal; taabbudî hükümlere müdahale, hikmet-i teşrî́yi ihmâl, mütekaddim fukaha ve geçmiş fıkıh müktesebatını tezyif ve benzeri şekillerde kendini gösterebilir.

Konu ile ilgili yazılmış eski yeni pek çok kaynak eser ve ilmî çalışma bulunmaktadır. Özellikle ülkemizde "hükümde değişme" ile ilgili yapılmış birçok çalışma olmakla birlikte konumuzla ilgili olması bakımından bu çalışmalara; Mehmet Erdoğan'ın, “İslâm Hukukunda Ahkâmın Değiş̧mesi" isimle kitabı ile Nihat Dalgın'ın, "Değişim Stratejisi Açısından Hukuk ve

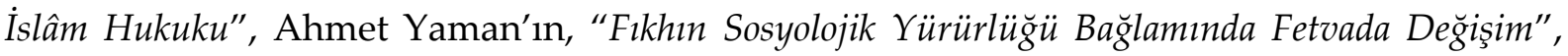
Yüksel Salman'ın, "Sosyal Değişme Ekseninde İslam Hukuku” adlı makaleleri örnek olarak gösterilebilir. Ayrıca usûl-i fıkıh kitaplarının büyük bir kısmında konu; ya hüküm ve fetvada değişim ya da örf ve maslahatın hükümlere etkisi başlıklarıyla ele alınmaktadır.

Biz bu çalışmada konuyu bütün yönleriyle değil, konu ile ilgili yapılan çalışmalarda büyük bir çoğunluğunun sehven yapıldığını düşündüğümüz yorum hataları etrafında ele alıp değerlendirileceğiz.

\section{Değişmenin Anlamı ve Hükümde Değişme Kavramı}

Değişme kavramı: “Bir nesnenin bir halden başka bir hale dönüşmesi ve farklılaşması veya cevheri itibariyle aynı kalmakla birlikte özündeki özellikleri bakımından farklılaşması" ${ }^{1}$ demektir. Arap dilinde ise "tebeddül" ve "tağayyür" kelimeleri ile ifade edilen bu kavram, "bir şeyin eski halinden başka bir hale dönmesi"² anlamına gelmektedir.

İllet ile hüküm arasındaki sebep sonuç ilişkisi, bir vakıaya ait illetin değişmesi sebebiyle doğal olarak hükmün de değişmesini gerektirir. Burada değişme ile kastedilen;

Ülker Gürkan, Hukukta Değişme, 310.

Ebü'l-Fazl Cemâlüddîn Muhammed b. Mükerrem b. Alî b. Ahmed el-Ensârî er-Rüveyfiî İbn Manzûr, Lisânü'lArab (Beyrût: Dârü Sâdır, 1414/1993), 11/48. 
hüküm değil, ictihâd ve fetvadır. Nitekim Şâtıbî (öl. 790/1388), "Âdetlerin farklılaşması sebebiyle hükümlerin farkhlaşması ile kastedilen, hitabın aslında meydana gelen bir farklılaşma değildir. Zira, şer' (şer'̂̂ hüküm) daimî ve ebedî olmak üzere konulmuştur. Burada sözü edilen farklılaşma, örfve âdetin değişmesi sebebiyle vakıa ile ilgili şer'î hükmün de değişmesi demektir"3 sözleriyle aslında şer'î hükmün değişmesinden fetvanın değişmesinin kastedildiğine vurgu yapmaktadır. İbn Kayyım el-Cevziyye'nin (öl. 751/1350), “İlâmü'l-muvakkıı̂̂n an Rabbi'l-'âlemîn” adlı eserinde konuyu, “Tağyîri'l-fetâvâ ve'htilâfiha"” başlığı ile ele alması ve Karâfî'nin (öl. 684/1285), ${ }^{5}$ hüküm ve fetvanın birbirinden farklı olduğuna ilişkin olarak, "el-İhkâm fî temyîzi'l-fetâvâ ani'lahkâm ve tașarrufâti'l-kạḍ̂ ve'l-imâm" ismiyle müstakil bir eser telif etmiş olmaları da bu tezi doğrulamaktadır.

Bu konuyu İbn Kayyım ve Karâfî’ den farklı olarak, “hükümde değişim” başlığı altında ele alan diğer fakihlerin konu ile ilgili verdikleri örnekler incelendiğinde müelliflerin aslında değişim sözü ile hükümde değişimi değil, ictihâd ve fetvada değişimi kastettikleri rahatlıkla görülecektir.6 Zira bu fakihlerin "hükümlerde değişme" başlığı altında verdikleri örneklerin ortak paydası, örfe müstenid ictihâd ve fetvalarda meydana gelen değişikliklerden başkası değildir.

Zira hakkında hüküm verilen bir vakıa değişmedikçe hükmün değişmesinden de söz edilemez. Buna göre, yeni ve farklı bir vakıa ile karşı karşıya olan bir müctehidin, yeni konuya ilişkin verdiği hüküm ile daha önce verilmiş bir hükmü değiştirdiği söylenemez. Dolayısıyla bu konunun, "hükümde değişme" başlığı ile değil de "fetvada değişme" başlığı ile ele alınması daha doğru olmakla birlikte biz bu çalışmamızda, galat-1 meşhur olan "hükümde değişim" tabirini kullanmaya devam edeceğiz.

\section{Hükümde Değişmenin İmkân ve Sınırlılıkları}

Değişme olgusunun evrenin kalıcı ve sürekli bir ilkesi ve temel bir gerçekliği olmasından ${ }^{7}$ hareketle, beşerî hukuk sistemlerinde olduğu gibi İslâm hukukunda da zan ifade

3 Ebû İshâk İbrâhîm b. Mûsâ b. Muhammed el-Lahmî el-Gırnâtî eş-Şâtıbî, el-Muvâfakāt (Beyrût: Dârü'l-Kütübi'lİlmiyye, 2003), 2/217.

4 İbn Kayyım el-Cevziyye, Ebû Abdillah Muhammed b. Ebî Bekr b. Eyyûb b. Sa'd Şemsüddîn, İlâmü'l-muvakḳ în an Rabbi'l-'âlemîn, ed. Muhammed Abdusselâm İbrahim (Beyrût: Dârü'l-Kütübi'l-İlmiyye, 1991), 3/11.

5 Karâfî, asıl adı Ebü'l-Abbâs Şihâbüddîn Ahmed b. İdrîs b. Abdirrahmân el-Mısrî olan bir Mâliki fakihi ve usûl âlimidir.

6 Daha geniş bilgi için bk. Özdemir, “Ahkâmın Değişmesi'ne Farklı Bir Yaklaşım”, 24.

7 Cevizci, Felsefe Sözlü̈̆̈̈̈, 125. 
eden naslar ile daha çok hakkında nas ve icmâ' bulunmayan sınırsız bir alanda ictihâd yoluyla hükümlerin değişmesi ve farklılaşması mümkündür.

Diğer hukuk sistemlerinden farklı olarak İslâm hukuku, bünyesinde bulunan az sayıdaki değişmez ilâhî yasalarla birlikte çoğu müctehidlerin çaba ve gayretleri ile şekillenen çift yönlü bir işleyişe sahiptir. Bu yönüyle İslâm hukuku, bir taraftan sahip olduğu değişmez kat'î şer'î hükümlerle hukukun bütünlük ve istikrârını sağlarken, diğer bir taraftan da değişen olgular karşısında ictihâda imkân veren esnek ve dinamik bir duruş sergilemektedir.

Nitekim İmamü'l-Haremeyn el-Cüveyni'nin bu hususta serdettiği (öl. 478/1085), “insaf ehli bir kimse kazâ ve fetvalara baktığında onların onda dokuzunun haklarında açık nas bulunmayan konularla ilgili rey' ve istinbattan ibaret olduklarını görür"9 şeklindeki sözleri ile "ezmânın tağayyuru ile ahkâmın tağayyru inkâr olunamaz"10 küllî kâidesi aslında bu gerçeği açıkça ifade etmektedir.

İctihâd ve hükümlerin değişmesi bağlamında âlimler arasında vaki olan ihtilâf; delil ve hüccet ihtilâfı değil, zaman ve mekâna bağlı olarak ortaya çıkan;11 örf- âdet, zaruret, maslahat ve benzeri değişkenlerle ilgili ihtilaftır.

Aslında bir konu hakkında birbirinden farklı birden çok ictihâdî görüşün olması, hükmün uygulanması ve ümmete kolaylık sağlaması bakımından oldukça önemlidir. Ayrıca bu husus, İslâm hukuku için de bir zenginlik ve bir meziyettir. İslam hukukunun zengin fıkıh müktesebatı içinde aynı konu ile ilgili farklı ictihâd ve fetva bulmak mümkündür. Bu ictihâd farklılığ1 çoğu zaman ictihâdî hükümde, nadiren de olsa kat'î şer'î hükmün uygulama biçim ve keyfiyeti ile ilgili olarak ortaya çıkabilmektedir.

\section{a. İctihâdi Hükümde Değişiklik:}

Mütekaddim Hanefî İmamları, ibadet olduğu gerekçesiyle Kur'an öğretimi karşılığında ücret almanın caiz olmadığı hususunda ittifak etmişlerdir. Ancak müteahhir Hanefî âlimleri, Kur'an öğretme, imamet ve müezzin-kayyımlık gibi din hizmetleri karşılığında devletin verdiği tahsisatın kesilmesi üzerine bu görevleri yapacak kimse kalmadığından bu hususta ücret almanın zarureten cevâzına hükmetmişlerdir. ${ }^{12}$ Özellikle

8 Zuhaylî, Vecîz, 2/311-313.

9 İmâmü'l-Haremeyn Ebü'l-Meâlî Rüknüddîn Abdülmelik b. Abdillâh b. Yûsuf el-Cüveynî, el-Burhân fì ușûli'lfiḳh, ed. Salâh b. Muhammed b. Uveyda (Beyrût: Dârü'l-Kütübi'l-İlmiyye, 1997), 2/15.

10 Ali Haydar, Dürerü'l-hükkâm şerhu Mecelleti'l-ahkâm (Beyrût: Dârü'l-Kütübi'l-İlmiyye, ts.), 1/1/47; Mecelle, Md. 39.

11 İbn Âbidîn, Resâili İbn 'Âbidîn, 2/126.

12 Ebü'l-Hasen Burhânüddîn Alî b. Ebî Bekr b. Abdilcelîl el-Fergānî el-Mergīnânî, el-Hidâye fì şerhi bidâyeti'lmübtedî, ed. Tallâl Yusuf (Beyrût: Dâr-ü İhyâi't-Türâsi'l-Arabî, ts.), 3/238; Zeynüddîn b. İbrâhîm b. Muhammed 
ülkemizde din hizmetleri sınıfına maaş tahsis edilmesinden sonra, "mâni zâil oldukta memnu" avdet eder"13 küllî kâidesi gereğince sonraki bu hükmün de değiştiği ve mütekaddim fukahanın tahrim hükmünün yeniden avdet ettiğini söyleyebiliriz. Bu tıpkı, zengin olan birinin servetine ulaşma imkânı bulunmadığında zekât almasının câiz, servetine kavuştuğunda ise zekât almasının haram olması gibidir. ${ }^{14}$

Hz. Ömer'in müellefe-i kulûb'a zekâttan pay vermemesi, kendi zamanında ayette geçen "İslâm'a ısındırma" illetinin tahakkuk etmemiş olması sebebiyledir. Zira Hz. Ömer zamanında Müslümanlar güçlenmiş ve gayr-i Müslimlerin kalplerinin İslam'a 1sındırılmasına da ihtiyaç kalmamıştır. Bu durum, onların bu maksatla kendilerine verilen zekâttan menedilmelerini gerektirir. Müslümanların zayıfladığı ve gayr-i Müslimlerin himayelerine ihtiyacın yeniden zuhur ettiği dönemlerde ayette geçen hüküm aynen geçerlidir. Nitekim Hz. Ömer b. Abdülaziz, kendi hilafeti döneminde Hristiyan din adamlarına zekâttan pay vermiştir. ${ }^{15}$ Buradaki vaki olan değişim, şer î hükmün makâsıd'ında (bizzat kendisinde) değil, hükmün vesâilinde (edâ ve uygulama biçiminde) ortaya çıkmaktadır.

Hz. Ömer'in aynı konu ile ilgili verdiği farklı ictihâdlar da hükmün değişmesinin cevazına bir başka delil olarak zikredilebilir. Nitekim Hz. Ömer'e, bir mesele hakkında daha önce verdiği fetvaya muhalif fetva vermesinin sebebi sorulduğunda: “O zaman öyle fetva vermiştik, şimdi ise böyle hükmettik" demiştir. Ayrıca Şa'bî'nin (öl. 104/722), “hadler konusunda Hz. Ömer'den yetmiş mesele öğrendim, ancak bu hükümlerden bazıları diğer bazılarına benzemiyordu" ${ }^{16}$ şeklindeki sözleri de bunu desteklemektedir.

Örf ve âdetlerin değişmesine rağmen önceki fetvalar ile yetinmenin cinâyet ve dalâlet olduğu hususunda âlimler arasında bir ihtilaf yoktur. Nitekim İbn Kayyım el-Cevziyye'nin, “örf-âdet, zaman ve durumun farklılığına rağmen insanlara, kitaplarda nakledilen görüşlerle fetva veren kişi, kendisi saptığı gibi başkalarını da saptırır. Böylelerinin dine karşı işlediği cinayet, eski tıp kitaplarındaki bilgilerle insanları tedaviye kalkışan doktorun cinayetinden daha büyüktür"17, İbn Âbidîn'in, (öl. 1252/1836), “bir müftînin kendi zamanının gerekleri ve

el-Misrî İbn Nüceym, el-Bahrü'r-râik şerhu kenzi'd-dekāị mea' tekmileti 'Ali et-Tûrî (Dârü'l-Kitâbi'l-İslâmî, ts.), $3 / 64$.

13 Ali Himmet Berkî, Açıklamalı Mecelle (Mecelle-i Ahkâm-ı Adliyye) (İstanbul: Hikmet Yayınları, ts.), 24.

14 Alâüddîn Ebû Bekr b. Mes'ûd b. Ahmed el-Kâsânî, Bedâ'i 'u'ṣ-șanâ'i fì tertîbi'ş-şerâ'i', ed. Ali Muhammed Muavvad-Adil Ahmed Abdulmevcud (Beyrût: Dârü'1-Kütübi'l-İlmiyye, 2002), 2/46.

15 Bk. Muhammed el-Biltâcî, Menhecü 'Umar b. el-Hatțâb fi't-teşrî; ts., 189.

16 Muhammed b. Ahmed b. Ebî Sehl Şemsü'l-eimme es-Serahsî, Ușûlü's-Serahsî (Beyrût: Dârü'l-Ma'rife, ts.), 16/84.

17 İbn Kayyım el-Cevziyye, İlâmü'l-muvakkıı în, 66. 
toplumunun örf ve âdetlerini gözetmeksizin zâhirü'r-rivâye kitaplarında yazılı olan nakillerle fetva vermesi, birçok hakkın zayi olması, hatta faydasından çok zarara sebep olması sebebiyle caiz değildir"18, Karâfî’nin, "müftî'nin, kendisinden fetva isteyen yabancı bir kimseye kendi beldesinin örfüne göre yazılmış kitaplardan menkul fetvalar vermesi caiz değildir. Bu kimseye beldesinde câri olan örfün sorulması ve ona göre fetva verilmesi gerekir, aksi ise dalâlettir"19 şeklindeki sözleri, ictihâdın gerekliliği ile her asırda devamının lüzumunu ortaya koyması bakımından oldukça anlamlıdır.

Hükümdeki bu tür değişikliklerin kısır bir döngü olduğunu vehmetmek doğru değildir. Aksine bu, İslâm hukukunun ictihâd mekanizması ile sağladığı dinamizmin net bir göstergesidir.

\section{b. Kat'î Şer'î Hükmün Vesâilinde (Edâ Keyfiyeti) Değişiklik:}

Asıl ve mahiyetleri itibariyle değişime kapalı olan hükümlerin, vesâilleri bakımından ictihâda konu olmaları mümkündür. Nitekim Hz. Ömer'in Basra ve Kûfe'den gelen hacı adayları için "zâtı 1rk"1 yeni mîkâd yeri olarak tayin etmesi²0 ile müellefe-i kulûba zekâttan pay vermemesi, ${ }^{21}$ nüfusun artması ve şehirlerin kalabalıklaşması üzerine Hz. Osman'ın Cuma namazı için dış ezanı ihdas etmesi ${ }^{22}$ ve benzeri ictihâdlar bunun en açık örnekleridir. $\mathrm{Bu}$ örneklerdeki değişim konusu, taabbudî hükümlerin makâsıdı (özü ve mahiyeti) değil, vesâilleri (uygulama biçimi ve edâ keyfiyyeti) itibariyledir. ${ }^{23}$

Zekât malından kendisine pay verilmesini talep eden bir müşrike Hz. Ömer: “De ki: Gerçek, rabbinizden gelendir. Artık dileyen iman etsin dileyen inkâr etsin”24 ayetini okuyarak bu talebi reddeder. Bu durum tıpkı, fakir olduğu için zekât verilen birinin zengin olmasından sonra zekâttan menedilmesine benzemektedir. Nitekim Hz. Osman ve Hz. Ali de kendi hilafetleri zamanında bu grubu zekâttan menetmişlerdir. ${ }^{25}$

18 Muhammed Emîn b. Ömer b. Abdilazîz el-Hüseynî ed-Dımaşkī İbn Âbidîn, Mecmûatü resâili İbn Ẩbidinn, ts. $2 / 131$.

19 Ebü'l-Abbâs Şihâbüddîn Ahmed b. İdrîs b. Abdirrahmân el-Mâlikî el-Karâfî, Envârü'l-burûk fi envâi'l-furûk, ts. 176-177.

20 Buhârî, "Hacc", 13 (No. 1531).

21 Muhammed el-Biltâcî, Menhecü 'Umar b. el-Hatțâb fi't-teşrî̀', ts., 189.

22 Kâsânî, Bedâ'i 'u'ṣ-sanâ'i', 1/152.

23 Ahmet Yaman, “Fikhın Sosyolojik Yürürlüğü Bağlamında Fetvada Değişim”, Diyanet İlmî Dergi 50/2 (2014), 10.

24 el-Kehf $18 / 29$

25 Ebû Muhammed Muvaffakuddîn Abdullāh b. Ahmed el-Makdisî İbn Kudâme, el-Muġnî (Mektebetü'l-Kâhire, 1968), 6/475. 
Ancak şerî̀ hükümlerin vesâilleriyle ile ilgili bu ve benzeri uygulama değişikliklerinden hareketle, bu hükümlerde makâsıd bakımında da değişiklik yapmanın mümkün olduğu sonucuna ulaşılamaz.

\subsection{Değişime Etkisi Bakımından Hükmün Taabbudîlik ve Ta‘lîl Edilebilirliği}

İslâm hukukunda hükümlerde değişme, diğer bir ifade ile ictihâd imkânı, dinin sâbiteleri ile değil, zan ifade eden değişken hükümleri ile ilgilidir. Hükmün sâbit ya da değişken olmasında ise naslardaki taabbudîlik ve ta'lîl edilebilirlik vasıfları belirleyici rol oynamaktadir.

Şâri'in vaz' ettiği hiçbir hüküm, elbette illet ve hikmetten hâli değildir. Ne var ki, bu illet ve hikmetler doğru anlaşılamayabilir. Bu hükümlerden illetleri akılla kavranabilenlere “ma'kûlü'l-ma'na”, yani ta'lîlî hüküm; akılla kavranamayanlara ise "gayr-i ma'kûlü'l-ma'na “, yani taabbudî hüküm denilmektedir. ${ }^{26}$

Şâtıbî, taabbud ve ta'lil edilebilir hükümlerin tasnifi konusunda, "mükelleflere nispetle ibadetlerde asıl olan taabbudîliktir ve bu hususta manaya iltifat edilmez, âdetlerde ise asıl olan manaya iltifattır"27 diyerek taabbud ve ta'lîl edilebilir hükümlerle ilgili genel bir çerçeve çizmiş ise de bu kuralın istisnalarının bulunduğunu şu sözleriyle vurgulamaktadır: "nikahta mehir talebi, eti yenen hayvanların meşru kesim şartları, nisab ve miras payları ve benzeri gibi muâmelâtla ilgili bir çok hüküm taabudîdir." 28 Buna göre, muâmelât hükümlerin tamamının ta‘lîl edilebilir olduğunu söylemenin yanlışlığı ortadadır.

\section{Kat‘î Delillerle Sabit Olan Hükümlerde Taabbudîlik ve Değişmezlik İlkesi}

Sübût ve delâlet bakımından kat'î olan naslarla sabit olan hükümlerde daha önceden de söylediğimiz gibi değişim söz konusu değildir. Zira nas, hükümlerin değişmesine sebep olan örften daha kuvvetlidir. Nas'ın batıl olması söz konusu değilken, örfün batıl olma ihtimali ise kuvvetle muhtemeldir. ${ }^{29}$

\footnotetext{
26 Ebû Abdillâh Şemsüddîn Muhammed b. Muhammed b. Abdirrahmân el-Hattâb er-Ruaynî, Mevâhibü'l-celîl lişerhi Muhtașarı Ḩalîl (Dârü'l-Fikr, 1992), 1/177; Ebû Muhammed es-Sülemî ed-Dımaşkī İzzuddîn b. Abdisselâm, Kavâidü'l-ahkâm fî̀ meșâlihi'l-enâm (el-Kavâidü'l-kübrâ) (Kâhire: Mektebetü'l-Külliyyâti'l-Ezheriyye, 1991), 1/122.

27 Şâtıbî, el-Muvâfakāt, 2/228.

28 Şâtıbî, Muvâfakât, 2/234.

29 Haydar, Dürerü'l-Hükkâm, 1/47-48.
} 
Hükümlerdeki bu değişmezlik, hükmün bizzat yakîn ifade eden naslardan elde edilmiş olmalarından kaynaklanmaktadır. Nitekim, "Mevridi nasta ictihâda mesâğ yoktur"30 küllî kaidesi de bu gerçeği ifade etmektedir.

Değişime kapalı olan bu hükümler genel hatlarıyla; inanç, ibadet, ahlak ilkeleri, helaller, haramlar, hadler, kefaretler, nisâb ve miras payları gibi bir kısım mukadderât-1 şer'iyye olarak özetlenebilir. ${ }^{31}$

İslâm hukukunda değişmez hükümler haddi zatında, hukukun ana omurgasını oluşturmaktadır. Aynı zamanda bu hükümler, ta'lîl edilebilir hükümlerde yapılacak olan değişikliklerin şer’î maksatlara uygun bir şekilde yapılmasını da sağlayan bir istikrar unsurudur. ${ }^{32} \mathrm{Bu}$ yönüyle İslâm hukukunun, öteden beri beşerî hukuk sistemlerinin gerçekleştirmeye çalıştığı istikrarı gerçekleştirebilme imtiyazına da sahip ideal bir hukuk sistemi olduğu söylenebilir.

“Kuşkusuz bu Zikr'i (Kur'an'1) biz indirdik, onu koruyan da elbette biziz"33 ayetinden, Kur'an lafızlarının şeytanın müdahalelerinden korunduğu gibi, helal, haram, hadler, nisap miktarları, miras ve mukadderat ile ilgili değişmez yasalarının da artırma ve eksiltmeye karşı da korunduğu anlaşılmaktadır. ${ }^{34}$ Vahyin bu korunmuşluğu, Hz. Peygamber'in din ile ilgili sözlerinin de korunmuşluğunu gerektirir. Zira “O, kişisel arzularına göre konuşmaz. Onun konuştukları kendisine indirilmiş vahiyden başka bir şey değildir" 35; "Ben, peygamberler arasında benzeri gelip geçmemiş biri değilim, bana ve size ne yapılacağını da bilmem. Ben ancak bana vahy edilene uyarım. Ben yalnızca apaçık bir uyarıcıyım." "36; "Peygamberleri apaçık delillerle ve kutsal metinlerle gönderdik. Umulur ki düşünürler diye onlara indirdiklerimizi kendilerine açıklaman için sana da zikri indirdik" ${ }^{37}$ ayetlerinde söz konusu edilen Sünnetin de de vahiy olduğu hususunda şüphe yoktur. ${ }^{38}$

\footnotetext{
Berkî, Mecelle, Md. 14.

Zuhaylî, Vecîz, 2/312.

32 Recep Özdemir, "Fıkhî Hükümlerde Değişim ve Gelişim İmkânı”, The Journal of Academic Social Science Studies, 54 (2016), 217.

34 Ebû Ca'fer Muhammed b. Cerîr b. Yezîd el-Âmülî et-Taberî, Câmiu'l-beyân an tevîli âyi'l-Kurân, ed. Ahmed Muhammed Şâkir (Müessesetü'r-Risâle, 2000), 17/68.

35 en-Necm 53/3-4.

36 el-Ahkâf 46/9

37 en-Nahl 16/44

38 Ebû Muhammed Alî b. Ahmed b. Saîd b. Hazm el-Endelüsî el-Kurtubî ez-Zâhirî İbn Hazm, el-İhkâm fî uṣ̂uli'lahkâm, ed. Ahmed Muhammed Şâkir (Beyrût: Dârü'l-Âfâkı'l-Cedîd, ts.), 1/121.
} 
İmam Şafiî (öl. 204/820) "er-Risâle" isimli meşhur eserinde, "Allah, vahyine ve Peygamberinin sünnetine uymayı insanlara farz kıldı" dedikten sonra "Kitap" ve "hikmet" kavramlarının peş peşe zikredildiği ayetleri ${ }^{39}$ sıralayıp sonra da "bu ayetlerde geçen "hikmet" kavramı ile kastedilen, Hz. Peygamberin sünnetinden başkası değildir" ${ }^{\prime 4}$, der.

Kitap ve Sünnet'in sübût ve delâlet bakımından kat'î olup bir örfe istinaden vaz' edilmiş olan naslarının ictihâd alanı olup olmadığı hususu ihtilaflı11 ${ }^{41}$ olmakla birlikte, bir örfe müstenit olmayan kat'î delillerle sabit hükümlerin ictihada kapalı olduğu hususunda ise İslâm âlimleri arasında bir ihtilaf bulunmamaktadır. ${ }^{42}$

Asıl ve mahiyetleri itibariyle değişime kapalı olan bu hükümlerin, vesâilleri bakımından ictihâda konu edilebilmeleri ise mümkündür. Nitekim Hz. Ömer'in Basra ve Kûfe'den gelen hacı adayları için "zâtı 1rk"1 yeni mîkâd yeri olarak tayin etmesi ${ }^{43}$ ile müellefei kulûba zekâttan pay vermemesi, ${ }^{44}$ nüfusun artması ve şehirlerin kalabalıklaşması üzerine Hz. Osman'ın Cuma namazı için dış ezanı ihdas etmesi ${ }^{45}$ ve benzeri ictihâdlar bunun en açık örnekleridir. Bu örneklerdeki değişim konusu, taabbudî hükümlerin makâsıdı (özü ve mahiyeti) değil, vesâilleri (uygulama biçimi ve edâ keyfiyyeti) itibariyledir. ${ }^{46}$

Ancak şer'î hükümlerin vesâilleriyle ile ilgili bu ve benzeri uygulama değişikliklerinden hareketle, bu hükümlerde makâsıd bakımında da değişiklik yapmanın mümkün olduğu sonucuna ulaşılamaz.

\section{Hükümlerin Değişmesinde Hikmet-i Teşrî'ye Riâyet ve Usul İlminin Gerekliliği}

İslâm hukuk tarihinde hükümlerin değişmesini tamamen reddeden hiçbir âlim ya da gruptan söz edilemediği gibi her bakımından üzerinde ittifak edilen bir ilke ve metottan da söz edilememektedir. Durum böyle olmakla birlikte her mezhebin hüküm elde etmede

Bakara 2/129-151-231; Âl-i İmrân 3/164; en-Nisâ 4/113; el-Ahzâb 33/34; el-Cum'a 93/2.

40 Ebû Abdillâh Muhammed b. İdrîs b. Abbâs eş-Şâfiî, er-Risâle, ed. Ahmed Muhammed Şâkir (Misır: Mektebetü'1Halebî, ts.), 1/73.

41 Bu görüş Hanefîlerden sadece İmam Ebû Yûsuf'a göredir. Daha geniş bilgi için bk. Haydar, Dürerü'l-Hükkâm, $1 / 47$.

42 Muhammed b. Ebî Bekr b. Eyyûb b. Sa'd Şemsüddîn İbn Kayyım el-Cevziyye, İḡāsetü'l-lehfân min meșâyidi'şşeyțân, ed. Muhammed Azîz Şems (Mekke: Dârü Alemi'l-Fevâid, 1432), 1/570; Muhammed Mustafa Şelebî, Ta'lîlü'l-'ahkâm (Beyrût: Dârü'n-Nehdati'l-Arabiyye, 1981), 300; Haydar, Dürerü'l-hükkâm, 1/43; Serahsî, elMebsût, 2/122.

43 Buhârî, "Hacc", 13 (No. 1531).

44 Muhammed el-Biltâcî, Menhecü 'Umar b. el-Hatțâb fi't-teşrî̀, ts., 189.

45 Kâsânî, Bedâ'i 'u'ṣ-sanâ 'i', 1/152.

46 Ahmet Yaman, "Fıkhın Sosyolojik Yürürlügü Bağlamında Fetvada Değişim”, Diyanet İlmî Dergi 50/2 (2014), 10. 
kullandıkları -aslında birbirinden tamamen farklı olmayan- belli bir metodoloji ve usûllerinin olduğu bilinmektedir.

Ancak hadler de dahil bütün hükümlerde sınırsız değişiklik talebinde bulunan modern dönem ifrat görüş sahiplerinin, hükümler üzerinde gerçekleştirmeyi planladıkları değişme ile ilgili teklif ettikleri bir strateji ve usulleri ise bulunmamaktadır. Üstelik bu kimseler, işlevselliğini kaybettiği ve artık furu' üretme yöntemi olmaktan çıtı̆̆g gerekçesiyle, İslâm âlimlerinin çoğunluğunun kabul ettiği usûl-i fıkıh ilmini itibarsızlaştırma teşebbüslerinden de geri durmamaktadırlar. ${ }^{47}$ Halbûki usûl-i fıkıh ilmi, nevâzilin nasıl çözümleneceği hususunda müctehitlere, hükme nasıl ulaşıldığının anlaşılabilmesi için de mukallitlere rehberlik eden, aynı zamanda hukuk birliği ile istikrarının da teminatı olan bir ilimdir.

Bu eleştirilerin temelinde fıkıh usûlünün, furû üretme zamanında değil, sonradan telif edildiği ön kabulü yatmaktadır. Oysa söz konusu ilim, o dönemde kitap olarak yazılı olmasa da zihinlerde teorik olarak bulunmakta idi. Aksi halde mezheplere ait sayısız görüş ve fetvadaki iç tutarlılık ve tenasüp başka hangi yolla izah edilebilir? Fıkıh usûlü ilminin işlevini kaybettiği ve gereksiz olduğu iddiaları, Kitap ve Sünnet hükümlerinden bazılarının tarihsel olduğunu iddia eden revizyonist müsteşriklerin bu konudaki görüşleri ile de paralellik arz etmektedir. Nitekim Joseph Schacht (öl. 1969), İmam Şâfiî̀nin (öl. 204/819) "er-Risâle" isimli usûl eserini, o zamana kadar yerleşmiş uygulamayı geriye dönük olarak sistematik hale getiren ve hadisin otorite değerini yükselterek yeni hadislerin uydurulmasının da önünü açan bir çalışma olarak nitelemektedir. ${ }^{48}$

Usûl ilminin tarihsel olduğu ve işlevsizleştiğini iddia eden bu ifrat görüş sahibi gurubun, usûl ilmi yerine başka bir metod teklif edememiş olmaları bile tek başına, hükümlerde sınırsız değişimle ilgili görüş ve iddialarında ne kadar tutarsız olduklarını göstermesi bakımından yeterlidir. Aslında ictihâd faaliyetleri ile eş zamanlı olarak varlık gösteren kadim usûl ilminin işlevsizleştiği iddialarının odağında, usûl ilmi çerçevesinde vücut bulan fıkıh mirasımızı yok sayma gayretlerinin olduğu söylenebilir.

47 Daha geniş bilgi için bk. Ahmet Yaman, “Fıkıh Usûlü İşlevini Tamamladı Mı?”, Marmara Üniversitesi İlahiyat Fakültesi Dergisi 57/57 (24 Ocak 2020), 25-46.

48 Yaman, "Fıkıh Usûlü İşlevini Tamamladı Mı?", 27; İshak Emin Aktepe, “Schacht ve 'Şâfiî̀nin Hayatı ve Şahsiyeti Üzerine' Adlı Makalesinin Tahlil ve Tenkidi”, Hadis Tetkikleri Dergisi III/2 (2005), 58. 
Şâtıbî'nin "el-Muvâfakât" isimli eserinde yer alan, "usûl ilmi, Kitap ve Sünnet ile vaz" edilen; 'zarar vermek ve zarara zararla mukabele etmek yoktur' ${ }^{\prime 29}$; 'hiçbir günahkâr başkasının günah yükünü çekmez'50; 'Allah dinde zorluk dilememiştir'51; ' ameller niyetlere göredir' ${ }^{52}$ ve benzeri küllî esaslara dayanmaktadır. Bu şer'î küllî esaslar; ya varlık, yokluk ve üçüncü halin imkânsızlığı gibi aklî ilkelere, ya da şer'î delillerden elde edilen zarûriyyât, hâciyyât ve tahsîniyyât gibi makâsıd-1 şerîaya dayanmaktadır. Bu bakımdan usûl ilmi zannî değil, kat'îdir. Eğer usûl-i fıkıh ilminin esaslarından birinin zannî olması mümkün olsaydı, usûl-i dîn ilminin esaslarının da zannî olması gerekirdi ki, bu, âlimlerin ittifakıyla caiz değildir" ${ }^{\prime 2}$ şeklindeki sözlerinden, usûl ilminin zannî değil kat'î olduğu net bir şekilde anlaşılmaktadır.

Usûl ilminin, çoğunluğu İslam ülkelerinde faaliyet gösteren fıkıh konseyleri tarafından da hala furu fıkıh üretme mekanizması olarak kabul görmesi de aslında bu ilmin, ictihâd faaliyetleri için temel teşkil ettiğini göstermesi bakımından oldukça önemlidir. Diyanet İşleri Başkanlığı Din İşleri Yüksek Kurulu (Türkiye) başta olmak üzere, Mecmeu'l-Fıkhi'l-İslâmî (İslâm İşbirliği Teşkilatı), el-Mecmeu'l-Fıkhiyyi'l-İslâmî (Râbıta), Mecmeu'1-Buhûsi'1İslâmiyye (Ezher), Dâru'l-İftâi'l-Mısriyye (Misır), Mecmeu'l-Fıkhi'l-Hindî (Hindistan), elMeclisü'l-Ûrubbî li'l-İftâ ve'l-Buhûs (İrlanda), Hey'etü Kibâri'l-Ulemâ ve Lecnetü'd-Dâime li'l-Buhûs ve'l-Fetva (Suudi Arabistan) gibi farklı coğrafyalarda faaliyet gösteren pek çok fikıh konseyi ve fetva kurulu, Müslümanların çağdaş amelî fıkhî problemlerini çözerken sırasıyla şu iki yöntemi tercih etmektedirler. Bunların ilki, "tahric ictihâdı"; ikincisi ise "istinbât ictihadı"dır. İkinci yöntemin fıkıh usûlünün delil ve istinbat metotları ile fıkhın genel kurallarından yararlanılarak yapıldığı bilindiğine göre, bu tür bir ictihâd için fıkıh usûlünün de devreye alınması doğal olarak kaçınılmaz olmaktadır. Fetva kurullarının, fıkhî sorunların halli hususunda takip ettikleri usûl ve yöntemlerle ile ilgili olarak yayınladıkları resmi kararlar da bunu desteklemektedir. Örneğin, Mecma'ül-Fıkhi'l-İslâmî ed-Düelî, Ürdün'ün başkenti Amman'da 24-28 Haziran 2006 yılında gerçekleştirdikleri toplantıda aldıkları 152 (1/17) numaralı karar şu şekildedir: “Fetvada İslâm mezheplerinin muayyen metoduna iltizam esastır ve bu usûlden kayıtsız olarak fetva verilemez. Ayrıca Şerîatın kural ve sâbiteleri ile

49 Ebû Abdillâh Muhammed b. Yezîd Mâce el-Kazvînî - Muhammed Fuâd Abdülbâki, Sünen-i İbn Mâce (Dârü İhyâi'l-Kütübi'l-Arabiyye, ts.), "Ahkâm” 17; Ebû Abdillâh Mâlik b. Enes İbn Mâlik, el-Muvatța', ed. Muhammed Fuâd Abdulbâki (Beyrût: Dâr-ü İhyâi't-Türâsi'l-Arabî, ts.), "Akdiye" 31.

50 Fâtır, 35/18.

51 Hac, 22/78.

52 Buhârî, Buhârî, "Bed'ü'l-Vahy” 1; Ebü'l-Hüseyn Müslim b. el-Haccâc en-Nîsâbûrî, el-Câmi 'u'ș-ṣahịh, ed. Muhammed Fuâd Abdülbâki (Beyrût: Dâr-ü İhyâi't-Türâsi'l-Arabî, ts.), "İmâret" 45.

53 Şâtıbî, Muvâfakât, 1/19-23. 
İslâm mezheplerinin istikrâ yöntemiyle ulaştıkları ilke ve kurallardan istiğnâ edilerek, Müslümanları sıkıntıya sokacak fetvalar vermek caiz değildir." ${ }^{54}$

Ayrıca Türkiye Cumhuriyeti Diyanet İşleri Başkanlığı nezdinde faaliyet yürüten fetva kurulunun, fetva yöntemleri ile ilgili olarak başkanlığın resmî sitesinde yayınlamış oldukları şu açılamalar da benzer ifadeler içermektedir: “Kurul fetva verirken/soruları cevaplandırırken Kur'an ve Sünnet'in yanında sahabe kavillerinden, icmâ' ve müctehit imamların ictihatlarından da yararlanmaktadır. Kur'an'1 doğru ve sağlıklı anlama konusunda Sünnet'in ve Sahabe'nin yol göstericiliğini elzem addeder. Bununla birlikte dinî yaşantımızla ilgili ortaya çıkan yeni durumların ve problemlerin tamamının sadece geleneksel mirasımızdan hareketle her zaman çözülemeyeceği de göz önünde tutulur. Bu durumda dahi Kurul, salt aklı kullanarak çözüm üretmek yerine, Kur'an, Sünnet, İcma ve Kıyas eksenli bir çalışma yapmayı tercih eder." 55

Öte yandan usûl-i fıkıh ilminin, dış baskılarla şer'î hükümlerde yapılması muhtemel değişikliklere karşı İslam hukukunun bütünlük ve istikrârını da koruduğu söylenebilir. ${ }^{56}$

Ayrıca karşılaşılan güncel fıkıh problemlerinin halli hususunda, usulü fıkhın kuralları ile Şâri'in şer'î hükümlerde gözettiği maksatlara riayet edilmeyecek olursa, ictihâd yeti ve yetkisini haiz olmayanların kendi hevalarına göre fetva vermelerine mâni olmanın da imkân ve ihtimali kalmaz.

Usûl ilmine riayet etmeksizin hükümlerde değişiklik yapma girişimine, Ahzâb sûresinin 59. Ayeti ile ilgili yapılan bazı hatalı tefsir ve fetvalar örnek olarak gösterilebilir. “Ey Peygamber! Eşlerine, kızlarına ve mü’minlerin kadınlarına söyle: (Evden çıkarlarken) cilbâblarını (dış giysilerini) üzerlerine bürünsünler. Bu, tanınıp rahatsız edilmemeleri için daha uygundur"57 mealindeki ayette açıkça Müslüman kadınlara cilbâb giymeleri emredilmektedir. Cilbâb, bütün bedeni örten, günümüzde manto ya da ferâce olarak da bilinen tek parça bir elbisedir. ${ }^{58}$ Bütün tefsir kitaplarında bu ayetin nüzul sebebi olarak; Medine'deki bir grup fasığın, kaza-i hâcet ve benzeri sebeplerle dışarıya çıkmak zorunda

\footnotetext{
54 International Islamic Fiqh Academy (IIFA), “قرار بشأن الإسلام والأمة الواحدة، المذاهب العقدية والفقهية" (Erişim 1 Kasım 2020).

55 Diyanet İşleri Başkanlığı (DİB), “Din İşleri Yüksel Kurulu Başkanlı̆̆ı” (Erişim 1 Kasım 2021).

56 Türkiye'de 1980 askerî darbesini gerçekleştirenlerin, Diyanet İşleri Başkanlığından, “başörtüsünün dinî bir vecibe olmadığı" yönünde karar çıkarmalarını talep etmeleri üzerine kendilerine verilen resmi cevap için bk. “Devlet Bakanlığı'nın 31 Ocak 1985 gün ve 5.05/1391 sayılı yazısına ilişik Dışişleri Bakanlığı'nın 28 Ocak 1985 gün ve 800.000/KKVS-III/Sosyal İşler/227-107 sayılı yazısı"

57 el-Ahzâb 33/59.

58 Muhammed Ali es-Sâbûnî, Ravâiu'l-beyân tefsîru âyâti'l-ahkâmi mine'l-Kur'ân (İstanbul: Dersaadet, ts.), 2/353.
} 
kalan hür kadınlara -onları cariye zannederek- tacizde bulundukları için cilbâb ayetinin nazil olduğu anlatılmaktadır. Ayetin sebebi nüzulü olarak anlatılan bu rivayetler ile Şâri'in cilbâb emrinin birbiriyle ilişkilendirilmesi sonucu bazı âlimlerde, cilbâb emrinin sadece hür kadınlarla cariyelerin birbirinden temyiz edilmesi için emredildiği görüşünü tercih etmişlerdir. Hâlbuki hiçbir müfessir, ayetin nüzul sebebi olarak anlatılan bu hadiselerin, ortadan kalkması durumunda hükmün de kalkmasını gerektirecek bir illet olduğunu söylememiştir. ${ }^{59} \mathrm{Bu}$ ayette geçen cilbâb emrini, kadınların dişarı çıkarken tesettüre uygun harici bir dış elbise giymelerinin emredildiği şeklinde değil de ayetin indiği Arap toplumunun örf ve âdetlerinin bir gereği olarak tefsir ${ }^{60}$ etmek, Müslüman da olsalar cariyelerin fasıklar tarafından taciz edilmelerini Kur'an'ın meşru gördüğü şeklindeki bir yanılgıyı doğru kabul etmek anlamına gelir. ${ }^{11}$ Oysa Endülüslü âlimlerden İbn Hazm (öl. 456/1064) ve Ebû Hayyân'a göre (öl. 745/1344), ayette geçen cilbâb emrinin doğrudan muhatabı olanlar, -ister hür ister cariye olsun- mümine kadınlardır. Zira cariyeleri, cilbâb emrine muhatap mümine kadınların genelinden istisna etmek için açık bir delile ihtiyaç vardır, oysa böyle bir delil bulunmamaktadır. ${ }^{62}$ Çağdaş müfessir Muhammed Ali es-Sâbûnî (öl. 2021) de cilbâb emrinin muhatabı olmak bakımından hür ve cariye kadınlar arasında bir fark görmemektedir.63 Kanaatimize göre de doğru olan budur.

Söz konusu ayetteki cilbâb emrini dönemin örfü ile ilişkilendirenlerden biri de Tâhir b. Âşûr'dur (öl. 1879-1973). Âşûr, ayetteki cilbâb hükmünü, hür kadınları cariyelerden temyiz etmek illeti ile gerekçelendirmekle kalmayıp, “cilbab, bir Arap adetidir ve Arap olmayan toplulukların bundan nasibi yoktur" diyerek ayetin hükmünün tarihsel olduğunu iddia etmektedir. ${ }^{64}$ Hâlbuki ayette hükmün illeti açık olarak zikredilmemiştir. Bu durumda illetin ictihâd edilerek tespit edilmesi gerekir. İstinbat yoluyla tespit edilen ve zan ifade eden böyle

59 Yahya Yaşar, “Ahzâb Sûresi 59. Âyetin Sebeb-i Nüzûl Rivâyeti Üzerinden Tarihselliği Meselesinin Analitik Tahlili (Kur'an Yolu Tefsiri Özelinde)”, Kahramanmaraş Sütçü İmam Üniversitesi İlahiyat Fakültesi Dergisi 24 (01 Aralık 2014), 103.

60 Karaman Hayrettin vd., Kur'an Yolu (İstanbul: DİB Yayınları, 2012), 4/399-400; Muhammed Tâhir İbn Âşûr, Maḳāṣıdü'ş-şerîati'l-İslâmiyye, ed. Muhammed el-Habîb el-Hoca (Katar: Vezâretü'l-Evkâfi ve'ş-Şuûni'lİslâmiyye, 2004), 3/270.

${ }^{61}$ Ebû Muhammed Alî b. Ahmed b. Saîd el-Endelüsî el-Kurtubî ez-Zâhirî İbn Hazm, el-Muhallâ bi'l-âsâr (Beyrût: Dârü'l-Fikr, ts.), 2/249.

62 Muhammed b. Yûsuf b. Alî b. Yûsuf b. Hayyân el-Endelüsî- Siddîkî Muhammed Cemîl, el-Bahrü'l-muhît fi'ttefsîr (Beyrût: Dârü'l-Fikr, 1420/1999), 8/504; İbn Hazm, el-Muḥallâ, 2/249.

63 Sâbûnî, Ravâiu'l-beyân tefsîru âyâti'l-ahkâmi mine'l-Kur'ân, 2/355.

64 İbn Âşûr, Maḳāṣıd, 3/270. 
bir illet ile de şer’î kat'î bir hükmü değiştirmek yahut hükmünün geçerliliğini kaldırmak usûl ilmi açısından yanlıştır. ${ }^{65}$

Aslında bu yorum, hükümlerin değişmesi konusu ile değil, ayetin tarihselliği iddiası ile ilgilidir. Ancak böyle olmakla birlikte Nihat Dalgın konu ile ilgili bir makalesinde, vahiy dönemindeki İslam toplumunda cari olan örf sebebiyle konulmuş hükümlerin değişmesine Âşûr'un bu tarihselci yorumunu örnek olarak vermekte bir beis görmemiştir. ${ }^{66}$

\section{Hükümlerde Değişme ile İlgili Görüşs Ayrılıkları Üzerine Bir Tespit ve Değerlendirme}

Ahmet Yaman'ın, “Fıkhın Sosyolojik Yürürlüğ̈̈ Bağlamında Fetvada Değgişim”, Yüksel Salman'ın, "Sosyal Değişme Ekseninde İslam Hukuku” adlı makaleleri ile Mehmet Erdoğan'ın, "İslam Hukukunda Ahkamın Değişmesi” adlı kitabı başta olmak üzere bu alanda yapılmış çalışmaların bazılarında, değişmenin kapsam ve sınırlılıkları bağlamında şekillenen görüşler genellikle üç grupta incelenmektedir. ${ }^{67}$

$\mathrm{Bu}$ çalışmalara göre tefrit görüş: Klasik dönemden "kadim fukaha" 68 ile çağdaş ulemadan Mecelle şârihi Ali Haydar Efendi (öl. 1960) ve benzeri diğer Mecelle şârihleri ile Muhammed Zâhid el-Kevserî’nin (öl. 1952) temsil ettiği görüştür.69

Yaman ile Erdoğan'ın, bu görüşü tefrit görüş diye nitelemeleri; grup temsilcisi fukahanın, taabbudîliğin sınırlarını geniş tutmaları olarak gerekçelendirilmiştir.

Yazarlar bu grubun değişim stratejilerini şu şekilde özetlemişlerdir:

1. "Ezmânın tağayyuru ile ahkâmın tağayyuru inkâr olunamaz"70 Mecelle kaidesinde zikri geçen "hüküm" ifadesi mutlak değildir. Burada hüküm kavramı ile delile dayanmayan örfe müstenit hükümler kastedilmektedir.

2. Sübût ve delâlet yönünden kat'î naslarla sâbit hükümler asla değiştirilemez.

3. Değişme küllî hükümlerde değil, cüz'î hükümlerde geçerlidir.

4. Değişme hükümde değil, hükmün uygulanmasında gerçekleşmektedir. ${ }^{71}$

65 Sait Şimşek, Günümüz Tefsir Problemleri (Konya: Kitap Dünyası, 2011), 248.

66 Nihat Dalgın, "Değişim Stratejisi Açısından Hukuk ve İslâm Hukuku”, Ondokuz Mayıs Üniversitesi İlahiyat Fakültesi Dergisi 16 (2003), 92.

${ }_{67}$ Yaman, "Fıkhın Sosyolojik Yürürlüğü Bağlamında Fetvada Değişim”, 9; Mehmet Erdoğan, İslam Hukukunda Ahkâmın Değişmesi (İstanbul: Türkiye Diyanet Vakfı Yayınları, 2011), 91-99.

68 Kadim fukaha kavramını kullanan Mehmet Erdoğan, bu grubu temsil eden âlimlerin kimler olduğundan açıkça bahsetmemektedir. Erdoğan, Ahkâmın Değişmesi, 95.

69 Erdoğan, Ahkâmın Değişmesi, 95.

70 Berkî, Mecelle, Md. 39.

71 Erdoğan, Ahkâmın Değişmesi, 96. 
Bu çalışmalara göre ifrat görüş: Klasik dönemden, “bir konuda nas ile maslahat çatışırsa maslahat nasa tahsis ve beyân tarikiyle takdim ve tercih edilir"72 diyen Necmeddîn et-Tûfî (öl. 716/1316) ile modern dönemden, “içtihat, kural içeren bir nasın veya geçmişteki emsal bir durumun manasını anlama ve o kuralı öyle bir şekilde teşmil, tahsis ya da aksi halde ta'dil ederek değiştirme çabasıdır ki, bulunan yeni çözüm vasıtasıyla bu kural, yeni durumu içersin"73 diyen Fazlur Rahman'1n (öl. 1988) temsil ettiği görüştür.

Aklı naklin önüne geçiren ve nas ile sabit olsa bile bütün hükümlerin değişebileceğini savunan Muhammed Abdûh (öl. 1905) ile Muhammed İkbâl de (öl. 1938) bu gruba dâhil edilebilir. $^{74}$

Yaman ile Erdoğan'ın, bu grubu tefrit görüş diye nitelemeleri, genel olarak ibadetler dışındaki taabbudî hükümlerin sınırlarını alabildiğince daraltmaları ve maslahat karşısında neredeyse bütün muâmelât hükümlerinin değişebileceği fikrini savunmaları ile gerekçelendirilmektedir.

Yazarlara göre bu grubun değişim stratejileri şu şekildedir:

1. Bütün cüz'î fer'î hükümler tarihsel ve toplumsal şartlarla kayıtlıdır. Kur'an ve Sünnet ile belirlenmiş hükümler ile ahkâm ayetleri de buna dâhildir.

2. Kanun koyucunun kastının doğru anlaşılabilmesi için kanunun, hükmün sâdır olduğu döneme göre değil, mevcut şartlar göz önünde tutularak yorumlanması gerekir. Zira yürürlüğe girmesinden sonra kanun, kanun koyucunun iradesine bağlı olmaktan çıkmıştır. ${ }^{75}$

3. Kur'an'daki teşri'î naslar; yasama ruhu ve fiilî yasama ile ilgili olmak üzere iki gruba ayrılır.76 Değişebilen hükümler fiilî yasama ile ilgili olanlardır ve bunun da bir istisnası yoktur.

Bu çalışmalara göre mutedil görüş: İlk dönem yönetici ve fukahası ile son devir İslâm hukukçusu akademisyenlerin temsil ettiği görüştür. ${ }^{77}$

Yaman ve Erdoğan'a göre üçüncü grup, diğer iki gruptan daha dengeli, yöntemsel olarak da daha tutarlı oldukları gerekçesiyle mutedil görüş diye nitelendirilmiştir.

\footnotetext{
72 Ebü'r-Rebî' Necmüddîn Süleymân b. Abdilkavî et-Tûfî, Risâle fî riâyeti'l-maṣlaha, ed. Ahmed Abdurrahîm esSâyih (Kâhire: ed-Dârü'l-Misriyye'l-Lübnâniyye, 1993), 23.

73 Fazlur Rahman, İslâm ve Çă̆gdaşlık (Ankara: Ankara Okulu Yayınları, 2010), 65.

74 Soner Duman-Shaker Jabarı, “Çă̆daş Dönemde Usûl-i Fıkhın Yenilenmesi Tartışmaları”, Dinbilimleri Akademik Araştırma Dergisi 20/1 (Mart 2020), 203-204.

75 Yaman, "Fıkhın Sosyolojik Yürürlüğü Bağlamında Fetvada Değişim”, 9; Erdoğan, Ahkâmın Değişmesi, 91.

76 Rahman, İslam ve Çağdaşlık, 47; Erdoğan, Ahkâmın Değişmesi, 91.

77 Erdoğan, Ahkâmın Değişmesi, 99.
} 
Yazarlara göre bu grubun stratejileri şu şekilde özetlenebilir:

1. Nasların lafızları son derece önemli olmakla birlikte maksat ve maslahatlara da itibar edilmelidir.

2. Nas'ın hükmünün her dönem için aynı kaldığı ve değişmediği fikri kabul edilemez.

3. Taabbudî ahkâmın sınırları mümkün oldukça dar tutulmalıdır.

4. Cüz'î ahkâm ile küllî ve teşri'î hükümler karıştırılmamalıdır.78

Yaman ve Erdoğan'ın hükümlerde değişim konusu ile ilgili görüş farklılığı içinde olan gruplara ilişkin yukarıdaki görüş ve değerlendirmeleri, beraberinde cevaplanması gereken şu soruları da akla getirmektedir:

1. Mutedil görüş temsilcileri; ilk dönem yöneticileri ile fukahası ise, ${ }^{79}$ tefrit görüşün temsilcileri arasında zikredilen "kadim fukaha" tabiri ile hangi fukaha kastedilmektedir? ${ }^{80}$

2. Mutedil görüş temsilcileri olarak zikredilen son devir İslâm hukukçusu akademisyenler kimlerdir? ${ }^{81}$

3. Kendilerine özgü değişim stratejileri sebebiyle iftiharla takdim edilen mutedil görüş, bugüne kadar furû' fıkıh üretme konusunda hangi katkılarda bulunmuşlardır?

4. Mutedil görüşün değişim stratejilerine ilişkin, "ilkesel olarak lafızlara son derece önem vermekle birlikte maksat ve maslahatlara da itibar ettikleri, nasın hükmünün her dönem için aynı kaldığı ve değişmediği fikrini kabul etmedikleri, taabbudî ahkâmın sınırlarını mümkün oldukça dar tuttukları ve cüzî ahkâmı, küllî ve teşri hükümleriyle karıştırmadıkları" şeklinde tespit edilen değişim stratejileri kime aittir ve hangi ilmî kaynaktan iktibas edilmektedir? ${ }^{82}$

Yaman ve Erdoğan'ın yapmış oldukları çalışmalarda, tespitini yaptığımız yukarıdaki sorulara cevap niteliği taşıyan herhangi bir bilgiye rastlayamadık.

Ayrıca tefrit görüş temsilcilerinin stratejileri ile ilgili olarak dile getirilen şu ifadeler de kanaatimize göre sorunlu gözükmektedir:

"Her nasılsa verilmiş olan fetvanın asla değişmeyeceğini savunan tefrit yaklaşım, klasik fıkıh doktrinini, ilgili olduğu konuyu nihaî olarak çözüme kavuşturan ve son noktayı

\footnotetext{
Erdoğan, Ahkâmın Değişmesi, 99.

79 Erdoğan, Ahkâmın Değişmesi, 99.

80 Erdoğan, Ahkâmın Değişmesi, 95.

81 Erdoğan, Ahkâmın Değişmesi, 99.

82 Erdoğan, Ahkâmın Değişmesi, 99; Yüksel Salman, "Sosyal Değişme Ekseninde İslâm Hukuku”, İslâm Hukuku Araştırmaları Dergisi 32 (2018), 79; Yaman, "Fıkhın Sosyolojik Yürürlüğü Bağlamında Fetvada Değişim”, 9.
} 
koyan hükümler mecmuası olarak görmektedir. Hal böyle olunca mezheplerde yerleşik hale gelen fetvalar "nas" telakki edilip adeta kutsallaştırılmaktadır. Bu görüşte olanlara göre fetvanın dayanaklarını yitirmesi, delilinin zayıflığının ortaya çıkması, hükümden beklenen hedefe artık ulaştıramıyor oluşu, verildiği zamana göre şartların, toplumsal durumların, örfün başkalaşmış olması onu değiştirme gerekçesi yapılamaz"83

Yaman'a ait yukarıdaki bu ifadede temel problem; evvelki fetvaları nas gibi telakki edip kutsallaştıran fukahanın kimler olduğu tespitinin yapılmamış olmasıdır.

Konu ile ilgili olarak Erdoğan'ın, “genelde müctehid imamlar ve sonra gelen fukaha, en son uygulamaları İslam hukukunun değişmez aslî hükümleri olarak almış ve daha önceki uygulamalarla amel edilemeyeceği görüşünü benimsemişlerdir" ${ }^{\prime 84}$ şeklindeki cümlelerinden ise söz konusu fukaha ile "müctehid imamlar ve sonraki fukaha"'nın kastedildiği net bir şekilde anlaşılmaktadır.

Yaman ile Erdoğan'ın bu görüşün stratejilerine yönelik birbirine benzer tenkitleri sebebiyle şunlar söylenebilir: Esas itibariyle tenkit konusu kısmen doğru olsa da -genelleyici ve oldukça da ağır olması sebebiyle- usûl ve tenkit etiği itibari ile doğru olmadığı kanaatindeyiz.

Tefrit görüş'e mensup fukahanın, Ifrat görüş temsilcilerinden Tûfî ile ilgili değerlendirmeleri hakkında Erdoğan'ın yaptığı şu yorumda da benzer sorunlar gözükmektedir:

“Tûfî’nin görüşü aşırı olmakla birlikte ona yöneltilen tenkit ve ithamların çok ağır olduğunu kabul etmek gerekir. Onun hakkındaki ithamlar, tabakât kitaplarına dayandırılmakta olup bütün eserlerinin incelenmesi neticesinde varılmış kanaatler değildir. Mesela, elimizdeki Risâle'sinden bu ithamlara bir mesnet çıkarılamaz. ${ }^{85}$

Erdoğan'a ait olan yukarıdaki bu cümleler, aslında maslahatla ilgili usule aykırı görüşleri sebebiyle Tûfî́yi eleştiren fukahaya yönelik eleştiriler içermektedir. Şimdi bu eleştirileri sırasıyla görelim:

Aslında Tûfî́nin maslahatla ilgili görüşlerinde aşırı gittiğini kabul eden Erdoğan'a göre, Tûfî’ yi eleştirenlerin yaptığı en büyük hata; onun görüşlerini tartışmak yerine, Şiî olduğu ile ilgili hakkında çıkan rivayetlerle onu itibarsızlaştırmalarıdır. Hâlbuki Tûfí’yi eleştiren

\footnotetext{
83 Yaman, "Fıkhın Sosyolojik Yürürlüğü Bağlamında Fetvada Değişim”, 8; Salman, "Sosyal Değişme Ekseninde İslam Hukuku", 78.

84 Erdoğan, Ahkâmın Değişmesi, 97.

85 Erdoğan, Ahkâmın Değişmesi, 95.
} 
âlimler onu, mezhebî mensubiyeti sebebiyle değil, usûl ilmine ve ictihâd teâmüllerine aykırı olarak dile getirdiği batıl görüşleri sebebiyle eleştirmekte ve onun bu görüşünün İmâmiye Şiâ'sının bu husustaki görüşleri ile benzerliğine dikkat çekmektedirler. Kaldı ki Erdoğan’ın, Tûfî'yi eleştiren âlimlerin en mutedili olduğunu kabul ettiği Ebû Zehre ${ }^{86}$ bile, "maslahat, bütün aslî şer'î delillerin üstündedir." ${ }^{87}$ "nasların maslahatla çatışması halinde maslahatın, tahsis ve beyan tarikiyle nasa takdimi vacip olur" ${ }^{\prime 8}$ sözleri sebebiyle Tûfí’yi kıyasıya eleştirmektedir. Aynı zamanda Ebû Zehre, Tûfî'nin maslahatla ilgili görüşünün, nasların Peygamberden sonra bile nesh edilebileceğini söyleyen İmâmiye Şiâ'sının bu husustaki görüşü ile örtüştüğünü dile getirmekle kalmayıp, onun şiî olduğuyla ilgili İbn Receb'in (öl. 795/1393) Tabakât'ında ${ }^{89}$ yer alan bilgileri nakletmekten de geri durmamaktadır. ${ }^{90}$ Erdoğan'ın, Tûfî́yi tenkit ve ithamlarında ileri gittiği için hissî davranmakla suçladığı başta Muhammed Zâhid el-Kevserî̀1 ve Saîd Ramazan el-Bûtî'nin² (öl. 2013) de yaptıkları da aslında bundan başka bir şey değildir.

Diğer taraftan Ebû Zehre'ye göre Tûfî́nin, eserlerinde tezini ispatlamak için maslahatla çatışan bir tek nas bile göstermemiş olması ${ }^{93}$ ile yararı ile zararı eşit olan maslahatların hangisinin itibara alınacağ 1 hususunda kura çekmeyi teklif etmesi, ${ }^{94}$ onun maslahatla ilgili görüşlerinin usule ne kadar da aykırı olduğunun görülmesi bakımından oldukça dikkat çekicidir.

\section{Sonuç}

Ülkemizde "hükümlerde değişim" konusu ile ilgili yapılan ilmî çalışmaların bazılarında usûlî bazı yorum hatalarının yapıldığı göze çarpmaktadır. Bu yorum hatalarının başında, "hükümlerde değişim" başlığı yer almaktadır. Bu başlık iki yönden sakıncalı gözükmektedir. Birincisi bu başlık, hükümlerde değişmenin sadece ta'lîlî hükümleri değil, taabbudî hükümleri de içine alacak kadar kapsamlı olduğu vehmi vermekektedir. Oysa

86 Erdoğan, Ahkâmın Değişmesi, 93.

87 Ebü'r-Rebî' Necmüddîn Süleymân b. Abdilkavî b. Abdilkerîm b. Saîd el-Hanbelî et-Tûfî, Risâle fí riâyeti'lmașlaha, ed. Ahmed Abdurrahîm es-Sâyih (Kâhire: ed-Dârü'l-Misriyye'l-Lübnâniyye, 1993), 34-47.

88 Tûfî, Riâyeti'l-Maslaha, 23.

89 Abdurrahmân b. Ahmed İbn Receb, ez-Zeyl alâ TTabakăti'l-Hanâbile, ed. Abdurrahman b. Süleymân el-Useymîn (Riyad: Mektebetü'l-Ubeykân, 2005), 4/409-416; Ebü'l-Fazl Şihâbüddîn Ahmed b. Alî b. Muhammed elAskalânî, ed-Dürerü'l-kâmine fî a yâni'l-mieti's-sâmine, ed. Muhammed Abdulmuîd Dân (Saydarâbâd: Meclisu Dâireti'1-Meârifi'1-Osmâniyye, 1972), 2/295-300.

90 Ebû Zehre, İbn-i Hanbel, 361-363.

91 Muhammed Zâhid el-Kevserî, Makālâtü'l-Kevs_erî (Kâhire: Mektebetü't-Tevfîkiyye, ts.), 243-246.

92 Muhammed Saîd Ramazan el-Bûtî, Ḍavâbițüll-mașlaha fi'ş-şerîati'l-İslâmiyye (Beyrût: Müessesetü'r-Risâle, 1973), 202-203.

93 Ebû Zehre, İbn-i Hanbel, 359.

94 Tûfî, Riâyeti'l-Maslaha, 46. 
değişen, zannî delille sabit olan hükümler ile hakkında nas ve icmâ' bulunmayan hükümlerdir. İkincisi ise bu başlık aynı zamanda değişenin fetva değil, bizatihi hüküm olduğu yanlış algısına sebep olmaktadır. İşte bu iki sebepten dolayı “hükümde değişme” konu başlığı, ya "fetvada değişme" ya da "fetvada farklılaşma" şeklinde olmalıydı. Zira değişme aynı zamanda bozmak anlamına da gelmektedir. Hâlbuki bir müctehidin başka bir müctehide ait bir hükmü bozma salahiyeti yoktur.

Ayrıca bu çalışmalarda, "hükümde değişim” tezinin fetvada değişim tezi ile istidlal ediliyor olması da bir başka yorum hatasıdır. Bu hatalı bakış açısının, konunun her bir vâkıa'nın alacağı hükmün illetini inceleyen "tahkîkü'l-menât" yöntemi ile değerlendirilmemiş olmasından kaynaklandığ1 söylenebilir. ${ }^{95}$ Kaldı ki değişen, hüküm değil, bizzat olgunun kendisidir. Dolayısıyla burada hükümde değişmeden değil, değişen illete bağlı olarak verilmiş yeni bir hükümden söz edilebilir.

Diğer bir taraftan, vahyin nüzulü sırasındaki bir örfe istinaden verilmiş bir hükmün, örfün değişmesi sebebiyle değişip değişmeyeceği hususu da âlimler arasında ihtilaflıdır. Örneğin İmam Yusuf bu konuda, İmam Ebu Hanîfe ve İmam Muhammed'e muhalefet ederek, örfe müstenid bütün hükümlerin değişebileceği görüşünü savunmaktadır. ${ }^{96}$ Ancak kadınlara evlerinden çıktıklarında üzerlerine cilbâb (üst elbisesi) almalarını emreden ayeti kerimenin ${ }^{97}$ hükmünü, o dönemin örfüne istinaden verildiği algısından hareketle değiştirmeye kalkmak ve bu konuda İmam Yusuf'un görüşüne sığınmak kabul edilebilir bir şey değildir. Zira ilgili ayetteki "cilbâb" hükmünün illeti, iddia edilenin aksine açık değildir. Kaldı ki bu konuyu gündeme taşıyan Tâhir b. Âşûr, aslında hükmün değişmesinden değil, ilgili hükmün tarihselliğinden bahsetmektedir. Bu yönüyle bu iddia, hükmün değişmesi tezi ile ilgili olmadığından konumuzun dişındadır.

Hükümlerde değişme ile ilgili yapılan ilmî çalışmaların bazılarında gördügüumüz yorum hatalarından biri de hükümlerin değişmesi ile ilgili görüşleri sebebiyle âlimlerin iki gruptan birine nispeti ile ilgilidir. Nitekim bu çalışmaların birinde, tefrit görüş sahibi grubun temsilci profili ile ilgili olarak "genelde müctehidler ve sonra gelen fukaha"; mutedil görüş sahibi grubun temsilci profili ile ilgili olarak da "son devir İslam hukukçusu akademisyenler" şeklinde son derece genel ve belirsiz bir tanımlama yapıldı̆̆ı görülmektedir.

\footnotetext{
95 İbrahim Özdemir, "Ahkâmın Değişmesi'ne Farklı Bir Yaklaşım", Marmara Üniversitesi İlâhiyat Fakültesi Dergisi 47 (2014), 23-24.

96 Haydar, Dürerü'l-Hükkâm, 1/47.

97 Ahzâb, 73/59.
} 
Ayrıca bu çalışmaların bazılarında, tefrit grup temsilcileri içinde gösterilen âlimlerin, önceki âlimlerin verdikleri fetvaların asla değişmeyeceğini savundukları ve mezhepte yerleşik hale gelen fetvaları 'nas' gibi telakki edip kutsallaştırdıkları şeklindeki bir eleştiriye maruz bırakıldıkları gözlerden kaçmamaktadır. Tefrit grup temsilcilerine ait değişim stratejileri hakkında dile getirilen bu eleştirilerin, gruptaki bütün âlimler için geçerli olduğu vehmi verecek kadar genel ve incitici olması, tenkit etiği açısından daha büyük bir sorun olarak karşımızda durmaktadır.

Sonuç olarak; hükümde değişme ile ilgili söz konusu edilen gruplara ilişkin şunlar söylenebilir: Konu ile ilgili kaleme alınan ilmî çalışmalarda, grup temsilci profilindeki belirsizlik ve değişim stratejilerinin sübut problemi sebebiyle mutedil görüş diye bir görüşten bahsetmek, kanaatimizce mümkün görünmemektedir. Bu durumda, konu ile ilgi görüş beyan eden âlim ve araştırmacılar; hangi delille sabit olursa olsun bütün hükümlerde değişimi savunan revizyonist tarihselci modernist görüş ile kat'î delille sabit olan hükümlerin makâsıdlarını değişimin dışında tutan fukaha görüşü olmak üzere iki farklı kategoride mütalaa edilebilir.

Hüküm ve fetvanın değişmesinin imkânı ile ilgili olarak da özetle şunlar söylenebilir: Hükümlerin değişmesi ile ilgili İslâm hukukçuları arasındaki vaki olan ihtilaf, hükümlerin makâsıd ve vesâilleri ile ilgilidir. Kat'î delille sabit olan taabbudî hükümler, makâsıd bakımından değişime kapalı olsalar da edâ biçimi ve uygulama keyfiyetleri bakımından ictihâda konu edilmeleri mümkündür. Zannî delille sabit olan ta'lîl edilebilir hükümler ile hakkında nas ve icmâ' olmayan konularda ise örf-âdet, zaruret, mesâlih-i mürsele ve benzeri sebeplerle değişmenin mümkün olduğu hususunda ise zaten âlimler arasinda bir ihtilaf yoktur.

Değişime kapalı şer̂î hükümler, zannedildiğinin aksine fıkhın yenilenme ve gelişmesine mâni olmayıp, fetvada yapılacak olan değişikliklerin şer'î eksene uygun olarak gerçekleştirilmesini sağlaması bakımından fonksiyonel bir yapıya sahiptir. Bu yönüyle değişime kapalı şerîi hükümler ile usûl-i fıkıh, aynı zamanda İslâm hukuku için bir denge, güven ve istikrar unsurudur. 


\section{Kaynakça}

Aktepe, İshak Emin. “Schacht ve 'Şâfiî̀n nin Hayatı ve Şahsiyeti Üzerine' Adlı Makalesinin Tahlil ve Tenkidi”. Hadis Tetkikleri Dergisi III/2 (2005), 57-83.

Askalânî, Ebü'l-Fazl Şihâbüddîn Ahmed b. Alî b. Muhammed el-. ed-Dürerü'l-kâmine fî a yâni'lmieti's-sâmine. ed. Muhammed Abdulmuîd Dân. Saydarâbâd: Meclisu Dâireti'lMeârifi'l-Osmâniyye, 2. Basım, 1972.

Berkî, Ali Himmet. Açıklamalı Mecelle (Mecelle-i Ahkâm-ı Adliyye). İstanbul: Hikmet Yayınları, ts.

Biltâcî, Muhammed el-. Menhecü 'Umar b. el-Hुațțâb fi't-teşrî́, ts.

Buhârî, Ebû Abdillâh Muhammed b. İsmâîl b. İbrâhîm el-Cu'fî el-. el-Câmiu'ș-ṣahîh. ed. Muhammed Züheyr Nâsir en-Nâsır. Dârü Tavki'n-Necât, 1422/2001.

Bûtî, Muhammed Saîd Ramazan el-. Davâbițü'l-mașlaḥa fi'ş-şerîati'l-İslâmiyye. Beyrût: Müessesetü'r-Risâle, 1973.

Cüveynî, İmâmü'l-Haremeyn Ebü'l-Meâlî Rüknüddîn Abdülmelik b. Abdillâh b. Yûsuf el-. elBurhân fi ușûli'l-fikh. ed. Salâh b. Muhammed b. Uveyda. Beyrût: Dârü'l-Kütübi'lİlmiyye, 1997.

Dalgın, Nihat. "Değişim Stratejisi Açısından Hukuk ve İslam Hukuku". Ondokuz Mayıs Üniversitesi Ilahiyat Fakültesi Dergisi 16 (2003), 73-109.

Duman, Soner - Jabarı, Shaker. "Çağdaş Dönemde Usûl-i Fikhın Yenilenmesi Tartışmaları". Dinbilimleri Akademik Araştırma Dergisi 20/1 (Mart 2020), 199-233.

Ebû Zehre, Muhammed. el-İmâm Ahmed b. Hanbel: Hayâtühû ve 'așruhû-ârầühû ve fiḳhuh. Kâhire: Dârü'l-Fikri'l-Arabî, ts.

Endelüsî, Muhammed b. Yûsuf b. Alî b. Yûsuf b. Hayyân el- Cemîl, Siddîkî Muhammed. elBahrü'l-muhît fi't-tefsîr. Beyrût: Dârü'l-Fikr, 1420/1999.

Erdoğan, Mehmet. İslam Hukukunda Ahkâmın Değişmesi. İstanbul: Türkiye Diyanet Vakfı Yayınları, 7. Basım, 2011.

Haydar, Ali. Dürerü'l-hükkâm şerhu Mecelleti'l-ahkâm. Beyrût: Dârü'l-Kütübi'l-İlmiyye, ts.

Hayrettin, Karaman vd. Kur'an Yolu. İstanbul: DİB Yayınları, 2012.

İbn Âbidîn, Muhammed Emîn b. Ömer b. Abdilazîz el-Hüseynî ed-Dımaşkī. Mecmûatü resâ ili İbn Âbidîn, ts.

İbn Âşûr, Muhammed Tâhir. Makạș̣ıü̈ş-şerîati'l-İslâmiyye. ed. Muhammed el-Habîb el-Hoca. Katar: Vezâretü'l-Evkâfi ve'ş-Şuûni'l-İslâmiyye, 2004.

İbn Hazm, Ebû Muhammed Alî b. Ahmed b. Saîd b. Hazm el-Endelüsî el-Kurtubî ez-Zâhirî. el-İhkâm fî uṣûli'l-ahkâm. ed. Ahmed Muhammed Şâkir. 8 Cilt. Beyrût: Dârü'l-Âfâkı'lCedîd, ts.

İbn Hazm, Ebû Muhammed Alî b. Ahmed b. Saîd b. Hazm el-Endelüsî el-Kurtubî ez-Zâhirî. el-Muhallâ bi'l-âsâr. Beyrût: Dârü'l-Fikr, ts.

İbn Kayyım el-Cevziyye, Muhammed b. Ebî Bekr b. Eyyûb b. Sa'd Şemsüddîn. İgāasetü'l-lehfân min meșâyidi'ş-şeyțân. ed. Muhammed Azîz Şems. Mekke: Dârü Alemi'l-Fevâid, $1432 / 2011$.

İbn Kayyım el-Cevziyye, Muhammed b. Ebî Bekr b. Eyyûb b. Sa'd Şemsüddîn. İlâmü'lmuvakkıı în an Rabbi'l-'âlemîn. ed. Muhammed Abdusselâm İbrahim. 4 Cilt. Beyrût: Dârü'l-Kütübi'l-i̇lmiyye, 1991.

İbn Mâlik, Ebû Abdillâh Mâlik b. Enes. el-Muvatța: ed. Muhammed Fuâd Abdulbâki. Beyrût: Dâr-ü İhyâi't-Türâsi'l-Arabî, ts. 
İbn Manzûr, Ebü'l-Fazl Cemâlüddîn Muhammed b. Mükerrem b. Alî b. Ahmed el-Ensârî erRüveyfiî. Lisânü'l-'Arab. Beyrût: Dârü Sâdır, 3. Basım, 1414/1993.

İbn Receb, Abdurrahmân b. Ahmed. ez-Zeyl alâ Tabakāti'l-Hanâbile. ed. Abdurrahman b. Süleymân el-Useymîn. 5 Cilt. Riyad: Mektebetü'l-Ubeykân, 2005.

İzzuddîn b. Abdisselâm, Ebû Muhammed es-Sülemî ed-Dımaşkī. Kavâiidü'l-ahkâm fî meșâlihi'lenâm (el-Kavâiidü'l-kübrâ). Kâhire: Mektebetü'l-Külliyyâti'l-Ezheriyye, 1991.

Karâfî, Ebü'l-Abbâs Şihâbüddîn Ahmed b. İdrîs b. Abdirrahmân el-Mâlikî el-. Envârü'l-burûk fî envâa'l-furûk, ts.

Kâsânî, Alâüddîn Ebû Bekr b. Mes'ûd b. Ahmed el-. Bedâi 'u'ṣ-șanâi fî̀ tertîbi'ş-şerâi: ed. Ali Muhammed Muavvad - Adil Ahmed Abdulmevcud. Beyrût: Dârü'1-Kütübi'l-İlmiyye, 2. Basım, 2002.

Kazvînî, Ebû Abdillâh Muhammed b. Yezîd Mâce el- - Abdülbâki, Muhammed Fuâd. Sünen-i İbn Mâce. Dârü İhyâi'l-Kütübi'l-Arabiyye, ts.

Kevserî, Muhammed Zâhid el-. Makālâtü'l-Kevs_erî. Kâhire: Mektebetü't-Tevfîkiyye, ts.

Nîsâbûrî, Ebü'l-Hüseyn Müslim b. el-Haccâc en-. el-Câmi u'ṣ-șahîh. ed. Muhammed Fuâd Abdülbâki. Beyrût: Dâr-ü İhyâi't-Türâsi'l-Arabî, ts.

Özdemir, İbrahim. "'Ahkâmın Değişmesi'ne Farklı Bir Yaklaşım”. Marmara Üniversitesi Illâhiyat Fakültesi Dergisi 47 (2014), 19-42.

Özdemir, Recep. "Fıkhî Hükümlerde Değişim ve Gelişim İmkânı". The Journal of Academic Social Science Studies 54 (2016), 215-239.

Rahman, Fazlur. İslam ve Çă̆daşlık. Ankara: Ankara Okulu Yayınları, 6. Basım, 2010.

Ruaynî, Ebû Abdillâh Şemsüddîn Muhammed b. Muhammed b. Abdirrahmân el-Hattâb er-. Mevâhibü'l-celîl li-şerhi Muhtașarı Hualîl. Dârü'l-Fikr, 3. Basım, 1992.

Sâbûnî, Muhammed Ali es-. Ravâiu'l-beyân tefsîru âyâti'l-ahkâmi mine'l-Kur'ân. İstanbul: Dersaadet, ts.

Salman, Yüksel. "Sosyal Değişme Ekseninde İslam Hukuku". İslam Hukuku Araştırmaları Dergisi 32 (2018), 71-103.

Serahsî, Muhammed b. Ahmed b. Ebî Sehl Şemsü'l-Eimme es-. el-Mebsûț. Beyrût: Dârü'lMa'rife, 1993.

Şâfiî, Ebû Abdillâh Muhammed b. İdrîs b. Abbâs eş-. er-Risâle. ed. Ahmed Muhammed Şâkir. Misır: Mektebetü'l-Halebî, ts.

Şâtıbî, Ebû İshâk İbrâhîm b. Mûsâ b. Muhammed el-Lahmî el-Gırnâtî eş-. el-Muvâfakāt. 4 Cilt. Beyrût: Dârü'l-Kütübi'l-İlmiyye, 3. Basım, 2003.

Şelebî, Muhammed Mustafa. Ta'lîlü'l-'ahkâm. Beyrût: Dârü'n-Nehdati'l-Arabiyye, 1981.

Şimşek, Sait. Günümüz Tefsir Problemleri. Konya: Kitap Dünyası, 10. Basım, 2011.

Taberî, Ebû Ca'fer Muhammed b. Cerîr b. Yezîd el-Âmülî et-. Câmi u'l-beyân an te vîli âyi'lKurân. ed. Ahmed Muhammed Şâkir. Müessesetü'r-Risâle, 2000.

Tûfî, Ebü'r-Rebî' Necmüddîn Süleymân b. Abdilkavî b. Abdilkerîm b. Saîd el-Hanbelî et-. Risâle fî riâyeti'l-mașlaha. ed. Ahmed Abdurrahîm es-Sâyih. Kâhire: ed-Dârü'lMisriyye'l-Lübnâniyye, 1993.

Vâhidî, Ebü'l-Hasen Alî b. Ahmed b. Muhammed el-. Esbâbü'n-nüzûl. Demmâm: Dârü'l-Islâh, 1412/1991.

Yaman, Ahmet. “Fıkhın Sosyolojik Yürürlüğü Bağlamında Fetvada Değişim”. Diyanet İlmî Dergi 50/2 (2014), 7-21. 
Yaman, Ahmet. "Fıkıh Usûlü İşlevini Tamamladı Mı?" Marmara Üniversitesi İlahiyat Fakültesi Dergisi 57/57 (Ocak 2020), 25-46. https://doi.org/10.15370/maruifd.679183

Yaşar, Yahya. "Ahzâb Sûresi 59. Âyetin Sebeb-i Nüzûl Rivâyeti Üzerinden Tarihselliği Meselesinin Analitik Tahlili (Kur'an Yolu Tefsiri Özelinde)". Kahramanmaraş Sütçü İmam Üniversitesi İlahiyat Fakültesi Dergisi 24 (Aralık 2014), 89-127.

Zuhaylî, Muhammed Mustafa ez-. el-Vecîz fì uṣ̂̂li'l-fikhi'l-İslamî. 2 Cilt. Beyrût: Dârü'l-Hayr, 2006.

Türk Dil Kurumu (TDK), “Töz” (Erişim 28. Ağustos. 2020). https://sozluk.gov.tr/.

Diyanet İşleri Başkanlığı (DİB), "Din İşleri Yüksel Kurulu Başkanlığı" (Erişim 1 Kasım 2021). https://kurul.diyanet.gov.tr/FetvaYontem.

International Islamic Fiqh Academy (IIFA), “قرار بشأن الإسلام والأمة الواحدة، المذاهب العقدية "و الفقهية (Erişim 1 Kasım 2020). https://www.iifa-aifi.org/ar/2200\%20html 